\title{
Obesity and Insulin Secretion in Fasting High School Students
}

\author{
P. Garcia-Webb, A. Bonser, K. L. Wearne, and M. Gracey \\ Department of Clinical Biochemistry, University of Western Australia and Raine Medical Statistics Unit, Queen Elizabeth II Medical \\ Centre, Nedlands, and Gastroenterological Research Unit, Princess Margaret Hospita1, Perth, Western Australia, Australia
}

\begin{abstract}
Summary. The relationship between plasma glucose, serum insulin, serum C-peptide and obesity was studied in 320 fasting high school students (13-18 years old), as part of a Busselton population study. For males and females respectively plasma glucose was $4.5 \pm 0.4$ and $4.4 \pm 0.5 \mathrm{mmol} / 1$ (mean $\pm \mathrm{SD}$ ), serum insulin $0.51 \pm 0.35$ and $0.69 \pm 0.39 \log _{10}$ $(\mathrm{nmol} / 1 \times 100)$, and serum C-peptide $0.48 \pm 0.15$ and $0.55 \pm 0.14 \mathrm{nmol} / \mathrm{l}$. These sex differences were not statistically significant. Plasma glucose correlated with C-peptide $(\mathrm{r}=0.21, \mathrm{p}<0.001)$ and insulin $(\mathrm{r}=$ $0.32, p<0.001$ ), indicating greater secretion where fasting glucose was higher. Obesity, measured as skin fold thickness, was also associated with serum C-peptide $(\mathrm{r}=0.32, \mathrm{p}<0.001)$ and insulin $(\mathrm{r}=0.37, \mathrm{p}<$ $0.001)$.
\end{abstract}

Key words: Serum C-peptide, insulin secretion, obesity, plasma glucose, fasting, skin fold thickness.

Connecting peptide (C-peptide) and insulin are released from pancreatic $\beta$ cells in equimolar amounts [1]. The concentration of C-peptide immunoreactivity (CPI) in serum from peripheral blood has been used as an index of insulin secretion in normal people and in people with hypoglycaemia and diabetes $[2,3]$. However, little consideration has been given to the complex interaction between such variables as obesity, age, sex, plasma glucose concentration and CPI in either the fasting or the fed state. Surveys of the adult residents of the shire of Busselton, Western Australia, commenced in 1966 and have been repeated at three yearly intervals. The aim of the surveys included an investigation of the prevalence and incidence of diabetes and the detec- tion of early cardiovascular disease. The surveys were extended to include high school children in 1975. A continuation of the Busselton Population Survey provided an opportunity to investigate some of the complex variables associated with insulin secretion in a group of high school students [4].

\section{Materials and Methods}

Students aged between 13 and 18 years attending Busselton High School in Western Australia were invited to participate after informed consent had been obtained from both the subjects and their parents. Data recorded included age, weight, sex, height and midtriceps skin fold thickness [5]. Fasting blood was taken for analysis of plasma glucose (glucose oxidase [6]), serum insulin immunoreactivity (IRI, double antibody radioimmunoassay [7])and CPI. Percentage ideal body weight was calculated from standard weight tables for age, height and sex [8]. Subjects were randomly selected except that subjects who were not fasting were excluded. No attempt was made to modify subjects' diet prior to the study.

Serum CPI was measured by a modification of Heding's method [9] using the antibody to synthetic human C-peptide $\mathrm{M}$ 1230 [10]. Unknowns and standards were incubated with anti-Cpeptide at $4{ }^{\circ} \mathrm{C}$ for 24 hours, labelled C-peptide added and the incubation continued for a further 24 hours. Normal guinea pig serum and anti-guinea pig serum were added and after a further 24 hours at $4{ }^{\circ} \mathrm{C}$ the tubes were centrifuged, washed twice with aspiration and the precipitate counted in an automatic gamma counter. Hormone free serum (pooled human serum rendered free of insulin, proinsulin and $\mathrm{C}$-peptide by incubation with active charcoal for 24 hours at $20^{\circ} \mathrm{C}$ ) was added to standard tubes and used to assess non-specific binding. A locally written computer program calculated unknowns using a modified logit plot.

The antibody, M1230, has $11 \%$ cross reactivity with proinsulin [10]. The lower limit of sensitivity, $95 \%$ probability that a result could be distinguished from zero [11], was $0.02 \mathrm{nmol} / \mathrm{l}$.

Glucose to C-peptide ratio $(\mathrm{G}: \mathrm{CPI})$ was calculated by dividing plasma glucose concentration (mmol/l) by CPI (nmol/l). Correlations between CPI or IRI and other variables was by Pearson Correlation using a two-tailed test of significance. Differences between means were tested by Student's ' $t$ ' test. Statistical significance was stated to exist where $\mathrm{p}<0.005$. 
Table 1. Serum C-peptide immunoreactivity, plasma glucose, plasma glucose to serum C-peptide ratio and serum insulin immunoreactivity in 320 high school students

\begin{tabular}{lllll}
\hline & & $\mathrm{n}$ & mean & SEM \\
\hline Serum CPI & Males & 135 & 0.48 & 0.01 \\
nmoll & Females & 173 & 0.55 & 0.01 \\
& Total & 308 & 0.52 & 0.01 \\
Plasma & Males & 129 & 4.5 & 0.04 \\
glucose & Females & 177 & 4.4 & 0.04 \\
mmol/l & Total & 306 & 4.4 & 0.03 \\
Glucose: & Males & 131 & 10.3 & 0.3 \\
CPI ratio & Females & 168 & 8.4 & 0.2 \\
& Total & 299 & 9.2 & 0.2 \\
Serum log $_{10}$ & Males & 132 & 0.51 & 0.03 \\
IRI & Females & 184 & 0.69 & 0.03 \\
& Total & 316 & 0.61 & 0.02 \\
\hline
\end{tabular}

CPI = C-peptide immunoreactivity

$\log _{10}$ IRI $=$ insulin immunoreactivity expressed as $\log _{10}$ $(\mathrm{nmol} / 1 \times 100)$, see text

Mean serum IRI was $4.4,7.0$ and $5.9 \mathrm{mU} / \mathrm{l}$ for males, females and the total population respectively

In some subjects technical difficulties prevented the assay of all three variables CPI, glucose and IRI

\section{Results}

Samples of blood were taken from 320 students, 184 being females and 136 males. The mean and standard error of the mean for serum CPI, plasma glucose, log IRI and G:CPI are shown in Table 1 . There was no difference between the mean plasma glucose for males and females ( 4.5 and $4.4 \mathrm{mmol} / 1$ respectively). The mean for IRI is given as $\log _{10}(\mathrm{nmol} / 1 \times 100)$. The distribution of IRI results was markedly skewed to the right. The data were normalised by log transformation. Using the log transformed data, the \pm 1 SD scatter about the mean for the total population for serum IRI was 2-10 mU/l. The differences between males and females were not significant for any of the four variables (for IRI, $0.005<p<0.01$; $p>0.01$ for $\mathrm{CPI}$, glucose and $\mathrm{G}: \mathrm{CPI}$ ).

Subjects were divided into six groups, firstly on the basis of percent ideal body weight and secondly on the basis of skin fold thickness. Figure 1 shows the mean and SEM of serum CPI and IRI for the six groups, defined by percentage ideal body weight. There is little change in mean serum IRI until \% ideal body weight is $130 \%$ or more. Figure 2 shows the mean and SEM for serum CPI and IRI for the six skin fold thickness groups. The means of both CPI and IRI increase with increasing skin fold thickness.

\section{Discussion}

The mean CPI was $0.52 \pm 0.15 \mathrm{nmol} / 1( \pm 1 \mathrm{SD})$, similar to values obtained by other workers on much smaller numbers $[12,13]$. The range of results was from $0.25-0.96 \mathrm{nmol} / 1$. The small difference observed between males and females was not significant $(0.01$ $<\mathrm{p}<0.02$ ). The distribution of the results was approximately Gaussian and was not made more so by $\log$ transformation.

Linear regression analysis showed a positive correlation between CPI and each of the following: IRI, glucose, \% ideal body weight, and skin fold thickness (Table 2). The correlation between CPI and IRI is to be expected since the two are secreted in equimolar quantities. Glucose and CPI are known to be associated in the fed state since an increase in plasma glucose concentration results in insulin secretion. This correlation is now shown to exist in the fasting state as well, although the correlation coefficient is low. The correlations between CPI and the two indices of obesity have not been noted in fasting subjects previously and suggest that there is increased insulin secretion in the presence of obesity. Linear regression analysis also showed positive correlations of IRI with glucose, \% ideal body weight and skin fold thickness.

Fig. 1. Mean serum insulin immunoreactivity (clear) expressed as $\log _{10}($ IRI $n m o l / 1 \times 100)$ and mean serum C-peptide immunoreactivity (stippled) for subjects grouped by percent ideal body weight. Top hats show standard error of the mean 


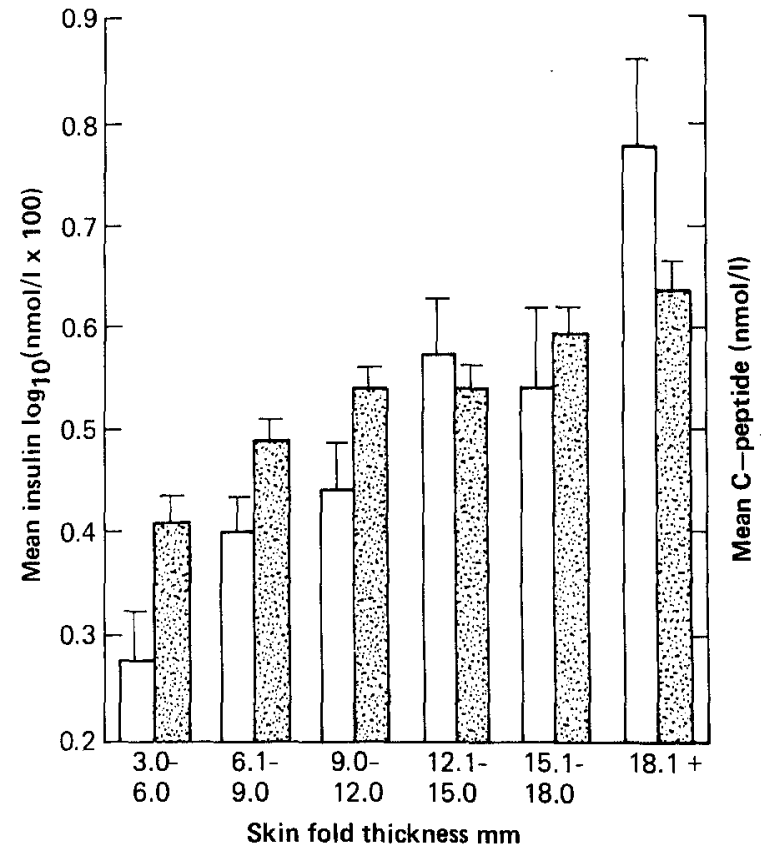

Fig. 2. Mean serum insulin immunoreactivity (clear) expressed as $\log _{10}($ IRI $\mathrm{nmol} / \mathrm{l} \times 100)$ and mean serum C-peptide immunoreactivity (stippled) for subjects grouped by skin fold thickness (mm)

Table 2. Pearson Correlation Coefficients between serum C-peptide immunoreactivity, serum insulin immunoreactivity, \% ideal body weight, skin fold thickness and plasma glucose. All correlations were significant, $\mathrm{p}<0.001$

\begin{tabular}{llll}
\hline & $\begin{array}{l}\text { Serum } \\
\text { CPI }\end{array}$ & $\begin{array}{l}\text { Serum } \\
\log _{10} \text { IRI }\end{array}$ & $\begin{array}{l}\text { Plasma } \\
\text { glucose }\end{array}$ \\
\hline $\begin{array}{l}\text { Serum CPI } \\
\begin{array}{l}\text { Serum } \log _{10} \\
\text { IRI }\end{array}\end{array}$ & 0.54 & \\
$\begin{array}{l}\text { Plasma } \\
\text { glucose }\end{array}$ & 0.54 & & \\
$\begin{array}{l}\text { \% ideal body } \\
\text { weight }\end{array}$ & 0.21 & 0.32 & \\
$\begin{array}{l}\text { Skin fold } \\
\text { thickness }\end{array}$ & 0.30 & 0.26 & -0.27 \\
\hline
\end{tabular}

CPI = C-peptide immunoreactivity

$\log _{10}$ IRI $=$ insulin immunoreactivity expressed as $\log _{10}$ $(\mathrm{nmol} / 1 \times 100)$, see text

Table 3. Number of male and female subjects in each of the arbitrarily defined groups of percent ideal body weight

\begin{tabular}{lll}
\hline$\%$ ideal body weight & Males & Females \\
\hline $80-90$ & 11 & 22 \\
$91-100$ & 43 & 50 \\
$101-110$ & 42 & 46 \\
$111-120$ & 20 & 32 \\
$121-130$ & 13 & 20 \\
$131+$ & 7 & 14 \\
\hline
\end{tabular}

Table 4. Number of male and female subjects in each of the arbitrarily defined groups of skin fold thickness

\begin{tabular}{lcc}
\hline $\begin{array}{l}\text { Skin fold thickness } \\
\text { (mm) }\end{array}$ & Males & Females \\
\hline $3.0-6.0$ & 31 & 2 \\
$6.1-9.0$ & 67 & 40 \\
$9.1-12.0$ & 26 & 44 \\
$12.1-15.0$ & 4 & 47 \\
$15.1-18.0$ & 5 & 26 \\
$18.1+$ & 3 & 25 \\
\hline
\end{tabular}

The correlation between $\%$ ideal body weight and fasting IRI has been noted previously [14]. The results suggest that fasting IRI (Fig. 1) is not greatly elevated for subjects with \% ideal body weight of less than $130 \%$. However, there does seem to be a trend for CPI to increase with \% ideal body weight over all six groups. Tables 3 and 4 show the number of males and females in each of the arbitrary subdivisions of $\%$ ideal body weight and skin fold thickness. There is little difference in the percentages of males and females in the six weight groups. However there is a large difference in skin fold thickness in males and females, with females having considerably greater skin fold thickness. Percent ideal body weight is not intended to be an index of fat mass; rather it is intended to show the comparison of an individual's mass with that of his or her peers. The fact that in females adipose tissue constitutes a greater percent of the body mass than it does in males is not demonstrated by ideal body weight tables. The measurement of skin fold thickness on the other hand does reflect this difference.

Figure 2 shows an increase of mean IRI and CPI with increasing skin fold thickness. The trend is more apparent than for \% ideal body weight and this is supported by the larger correlation coefficients between skin fold thickness and CPI and IRI (Table 2). These results support the suggestion that fasting insulin secretion correlates with adipose tissue mass. It is possible that the small differences between the sexes of mean IRI and CPI have their origin in the fact that females as a group have more adipose tissue than males.

A possible explanation for an increase in IRI and CPI in those with high skin fold thickness might be if the more obese coincidentally had a higher fasting glucose. This is not likely to be the case, as overall there was a negative correlation between skin fold thickness and glucose $(\mathrm{r}=-0.35, \mathrm{p}<0.001)$. In the absence of renal disease the glucose to CPI ratio may be considered to be an index of glucose stimulation of pancreatic insulin secretion. If the increased insulin 
secretion of obesity was due to an increase in fasting glucose concentration, the G:CPI ratio would be the same for small and large skin fold thickness. This was not the case, the G:CPI ratio showing an inverse correlation with skin fold thickness $(\mathrm{r}=-0.35$ $\mathrm{p}<0.001$ ).

To further test the hypothesis that increased adipose tissue mass resulted in increased insulin secretion the data were subjected to pathway analysis [15], an extension of multivariate analysis which tests the probability of causal relationships. The analysis was performed on the variables IRI, CPI, glucose, skin fold thickness and sex. The results of the analysis supported the following correlations:

(i) fasting glucose correlated with IRI and CPI irrespective of sex and skin fold thickness;

(ii) skin fold thickness correlated with IRI and CPI irrespective of glucose and sex;

(iii) IRI correlated with CPI irrespective of the results of the other 3 variables;

(iv) there was no difference between the effects of skin fold thickness on IRI and CPI and those of the female sex on IRI and CPI.

Acknowledgements. The authors are grateful for the assistance received from the Busselton Population Study Group, the Raine Medical Statistics Unit and Mr. H. Kavieri of the Department of Mathematics, University of W. A. This work was supported in part by a grant from the Diabetes Research Foundation of Western Australia, Inc.

\section{References}

1. Horwitz DL, Starr JI, Mako ME, Blachard WC, Rubenstein $\mathrm{AH}$ (1975) Proinsulin, insulin and C-peptide concentrations in human portal and peripheral blood. J Clin Invest 55: 1278-1283

2. Binder C, Faber OK (1978) Residual beta-cell function and its metabolic consequences. Diabetes 27 (Suppl 1): 226-229
3. Sandler R, Horwitz DL, Rubenstein AH, Kuzuya H (1975) Hypoglycaemia and endogenous hyperinsulinism complicating diabetes mellitus. Am J Med 59: 730-736

4. Curnow DH, Cullen KJ, McCall MG, Stenhouse NS, Welborn TA (1969) Health and disease in a rural community. Aust J Sci 31: $281-285$

5. Tanner JM (1959) The measurement of body fat in man. Proc Nutr Soc 18: 148-155

6. Kadish AH, Little RL, Sternberg JC (1968) A new and rapid method for the determination of glucose by measurement of rate of oxygen consumption. Clin Chem 14: 116-131

7. Hales CN, Randle PJ (1963) Immunoassay of insulin with insulin-antibody precipitate. Biochem J 88: 137-146

8. Jellife DR (1967) The assessment of the nutritional status of the community. WHO Monogr Ser 53: 230-233

9. Heding LG (1975) Radioimmunological determination of human C-peptide in serum. Diabetologia 11: 541-548

10. Faber OK, Binder C, Markussen J, Heding LG, Naithani VK, Kuzuya H, Blix P, Horwitz DL, Rubenstein AH (1978) Characterization of seven C-peptide antisera. Diabetes 27 (Suppl 1): 170-177

11. Jeffcoate SL, Gaines Das RE (1977) Interlaboratory comparison of radioimmunoassay results: variation produced by different methods of calculation. Ann Clin Biochem 14: 258-260

12. Kuzuya T, Matsuda A, Saito Y, Yoshida S (1976) Human C-peptide immunoreactivity (CPR) in blood and urine. Evaluation of a radioimmunoassay method and its clinical implications. Diabetologia 12: 511-518

13. Heding LG (1978) Insulin, C-peptide and proinsulin in nondiabetics and insulin treated diabetics. Diabetes 27 (Suppl 1): 178-183

14. Zimmet P, Whitehouse S, Alford F, Chisholm D (1978) The relationship of insulin response to a glucose stimulus over a wide range of glucose tolerance. Diabetologia 15: 23-27

15. Feinberg SE (1977) The analysis of cross classified discrete data. MIT Press, Cambridge, Massachusetts

Received: October 15, 1979, and in revised form: May 1, 1980

Dr. P. Garcia-Webb

Department of Clinical Biochemistry

University of Western Australia

Queen Elizabeth II Medical Centre

Nedlands, Western Australia

Australia 